\title{
Transcallosal Fibers from the Corticospinal Tract in Adults with Brain Injury
}

\author{
Sung Ho Jang, Sang Ho Ahn, Yun Woo Cho \\ Department of Physical Medicine and Rehabilitation, \\ College of Medicine, Yeungnam University, Daegu, Korea
}

-Abstract-

Background:Diffusion tensor image tractography (DTT) can visualize white matter tracts and provide us with a powerful vehicle for investigating the neuralpathway at the subcortical level. Using DTT, we attempted to demonstrate abnormal transcallosal fibers from the corticospinal tract in patients with brain injury.

Materials and Methods : Four adults with brain injury (2 patients: stroke, 1 patient: brain tumor with hemorrhage, 1 patient: diffuse axonal injury) and 14 normal control subjects were enrolled in this study. DTT was performed using 1.5- $\mathrm{T}$ with a Synergy-L Sensitivity Encoding head coil. Three-dimensional reconstructions of the fiber tracts were obtained with $\mathrm{FA}<3.0$, and an angle change $>45 \mathrm{o}$ as termination criteria.

Results : Transcallosal fibers were observed in two of 14 normal controls, and ascended to the cortex leaving the corpus callosum. All four patients showed transcallosal fibers which stemmed from the corticospinal tract of the unaffected hemisphere, and descended to or around the lesion at the subcortical area.

Conclusion : It seems that transcallosal fibers which arise from the corticospinal tract of the unaffected hemisphere may act as pathological fibers for motor deficit compensation.

Key Words : Diffusion tensor image, Brain injury, Interhemispheric inhibition, Corpus callosum.

Introduction

Diffusion tensor image tractography (DTT) is a recently-developed neuroimaging technology which provides an invaluable vehicle for the study of neuronal connectivity and the 
diagnosis of white matter pathophysiology. ${ }^{1-3)}$ By estimating water diffusion characteristics, DTT enables us to explicate the integrity and orientation of the white matter tracts; the process also allows for the three-dimensional visualization of transcallosal fibers. ${ }^{1-5)}$ Thus, we used this new neuroimaging technique to demonstrate the abnormal transcallosal fibers from the corticospinal tracts of patients with brain injury by comparing them to the normal transcallosal fibers which can be observed in normal subjects.

\section{Materials and Methods}

Subjects: Four right-handed patients with brain injury (3 men: mean age, 42 years; range, 29 to 62) and fourteen age-matched right-handed control subjects (8 men: mean age, 41 years; range, 22 to 63) with nohistory of neurologic disease were recruited and provided written consent (Table 1). This study was approved by our institutional review board.

We recruited 4 patients (2 patients: stroke;
1 patient: brainstem glioma with hemorrhage; 1 patient: diffuse axonal injury) according to the following criteria: (1) no history of previous brain injury; (2) shows hemiparesis at the time of DTT scanning and brain MRI evidence of focal lesion responsible for the hemiparesis and (3) showed abnormal trancallosal fibers that cannot be observed in normal controls.

The Standardized Motricity index (MI) was used to determine motorfunction. MI is a measure of integrity of motor function with a maximum score of 100.' Severe paralysis is defined as a score of $0-32$, moderate is defined as 33-64, and mild is defined as 65-99. The patients showed an average of 51.3 points (range, 33-67).

Diffusion tensor tractography: Diffusion tensor images were acquired using a 1.5-T Philips Gyroscan Intera system equipped with a Synergy-L Sensitivity Encoding (SENSE) head coil using a single-shot spin echo-planar imaging sequence. For each of the 32 noncollinear and noncoplanar diffusionsensitizing gradients, we acquired 60 contiguous

Table 1. Patients Demographic and Clinical Data

\begin{tabular}{cccccc}
\hline $\begin{array}{c}\text { Patient } \\
\text { No }\end{array}$ & $\begin{array}{c}\text { Sex/Age } \\
\text { (years) }\end{array}$ & $\begin{array}{c}\text { Duration } \\
\text { to DTT }\end{array}$ & Brain Injury Type & Lesion Site & $\begin{array}{c}\text { Motricity } \\
\text { Index }\end{array}$ \\
\hline 1 & $\mathrm{M} / 42$ & 39 months & Hemorrhage & Rt. Thalamus & 33 \\
2 & $\mathrm{~F} / 62$ & 2 weeks & Infarct & Lt. Corona Radiata & 46 \\
3 & $\mathrm{M} / 34$ & 6 months & Glioma with Hemorrhage & Lt. Midbrain & 59 \\
4 & $\mathrm{M} / 29$ & 5 months & Diffuse axonal injury & Lt. Brainstem & 67 \\
Mean $\pm \mathrm{SD}$ & $41.8 \pm 10.3$ & & & & $51.3 \pm 11.8$ \\
\hline
\end{tabular}

DTT; diffusion tensor image tractography. 
slices parallel to the anterior commissureposterior commissure line. The imaging parameters used were: matrix $=128 \times 128$ matrix; field of view $=221 \times 221 \mathrm{~mm}^{2} \mathrm{TE}=$ $76 \mathrm{~ms} ; \mathrm{TR}=10,726 \mathrm{~ms} ;$ SENSE factor $=2$; EPI factor $=67 ; \mathrm{b}=600 \mathrm{~mm}^{2} \mathrm{~s}^{-1} \mathrm{NEX}=1$; and a slice thickness of $2.3 \mathrm{~mm}$. We also evaluated the fiber connectivity using FACT (Fiber Assignment by Continuous Tracking), a 3-D fiber reconstruction algorithm contained within Philips PRIDE software. ${ }^{2)}$ The termination criteria used were $\mathrm{FA}<0.3$, and an angle change $>45^{\circ}$. A seed region of

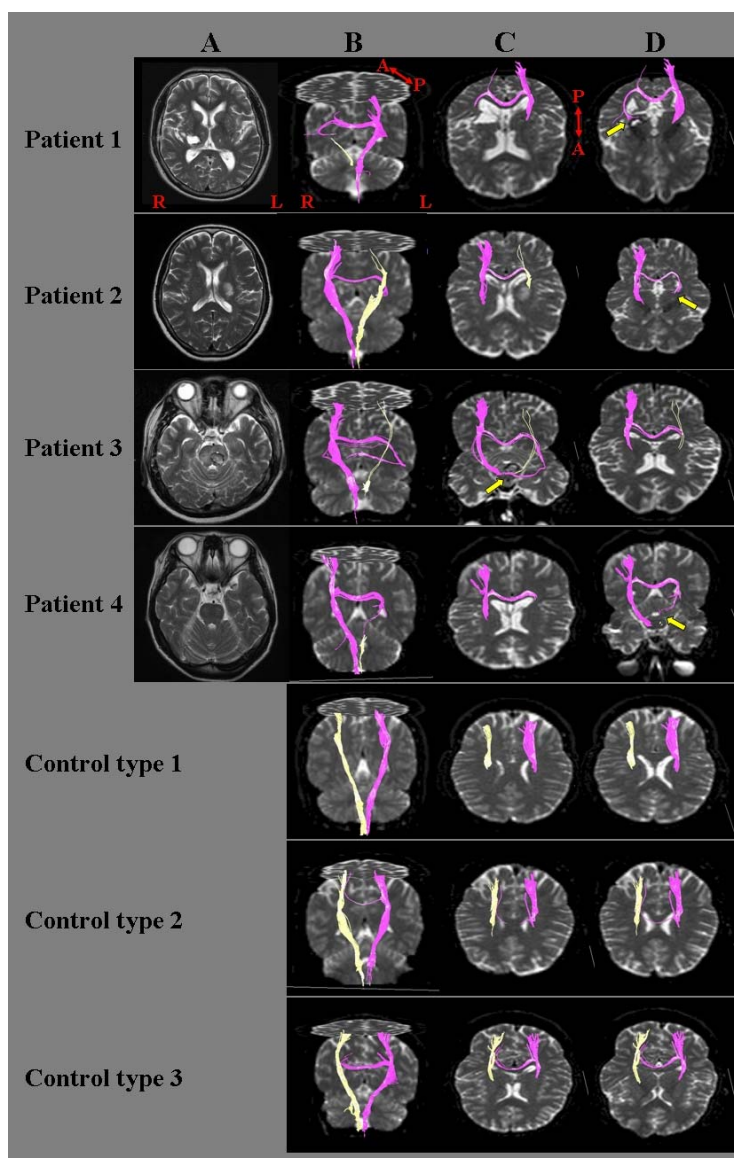

interest (ROI) was drawn in the corticospinal tract portion of the anterior pons on a $2-\mathrm{D}$ FA color map, and another ROI was drawn in the corticospinal tract portion of the anterior lower pons on a 2-D FA color map. Fiber tracts passing through both ROIs were designated as the final tracts of interest.

\section{Results}

In control subjects, the motor tract originated from the motor cortex and consecutively descended through the corona radiata, the

Fig. 1. T2-weighted images of the brain lesion (arrow) (A). Patient 1 - leukomalactic change following hemorrhage on the right thalamus, patients 2 infarct on the left corona radiata, patient 3 hemorrhage in the glioma of the left pons, and patient 4 -mild atrophy of the left pons due to diffuse axonal injury. Combined coronal and axial images (B), axial images at the splenium level of the corpus callosum (C), and axial images at or around the lesion level (D). All four patients showed transcallosal fibers originating from the corticospinal tract of the unaffected hemisphere (purple color). Those fibers passed through the splenium of the corpus callosum and descended inferiorly to the lesion, ending in or around the lesion (yellow arrow). There are three type of DTT in normal controls. Control type 1 - no transcallosal fibers, 12 of 14 controls corresponded to this type. Control type 2 - the transcallosal fibers pass through the body of the corpus callosum and then ascended to the motor cortex, one of 14 controls correspondedto this type. Control type 3 - the transcallosal fibers pass through the splenium of the corpus callosum and then ascended to the parieto-occipital cortex, the one remainingcontrol corresponded to this type. 
posterior limb of the internal capsule, the cerebral peduncle of the midbrain, the anterior pons, and the anterior medulla on all DTTs (Fig. 1). There are three types of DTT which concern the transcallosal fibers in normal controls. Transcallosalfibers were not observed in 12 of 14 controls (control type 1). Transcallosal fibers were observed in 2 of 14 controls one of them passed through the body of the corpus callosum, after which it ascended to the motor cortex (control type 2 ), and the other ascended to the parietooccipital cortex after passing through the splenium of the corpus callosum (control type 3).

On the DTT of the patients, all four patients showed transcallosal fibers originating from the corticospinal tract of the unaffected hemisphere. Those fibers passed through the splenium of the corpus callosum and descended inferiorly to the lesion, finally ending in or around the lesion. These findings were not observed in normal controls. In patient 1, we observed an ascending branch from the transcallosal fibers of the corticospinal tract of the unaffected hemisphere.

\section{Discussion}

According to the results of the current study, it is believed that the transcallosal fibers observed in these patients would be abnormal compared to those of normal controls. Only 2 of 14 normal controls showed transcallosal fibers that ascended superiorly to the cortex after leaving the corpus callosum. On the contrary, the patients showed transcallosal fibers that descended inferiorly to the subcortical lesion. Considering that all of the transcallosal fibers from the CST of the unaffected hemisphere in patients ended in or around the lesion, there appears to be a possible association with compensation for motor deficit. However, further investigation should be conducted in order to determine the clinical significance of the transcallosal fibers which passed through the splenium of the corpus callosum and are known to be associated with visual function.

A majority of research regarding the motor recovery mechanism following brain injurysuggested four possible mechanisms: (1) cortical reorganization around the damaged primary motor cortex, (2) the ipsilateral motor pathway from the unaffected motor cortex to the affected extremities, (3) substitution of the secondary motor areas, and (4) recovery of the damaged contralateral corticospinal tract. $^{8-10)}$ Of these mechanisms, the ipsilateral motor pathway has been the most actively researched and has been reported in several diseases. 9, 10) Although several hypotheses have been proposed regarding the ipsilateral motor pathway, the putative mechanism of this proposed motor recovery is the disinhibition hypothesis. ${ }^{10-13)}$ The normal motor cortexes maintain balance through transcallosal inhibition. However, if brain 
injury occurs, interhemispheric transcallosal inhibition from the affected side toward the unaffected side decreases. Therefore, recruitment of the unaffected motor cortex occur as the population of potentially available neurons increases as a means of counteracting the loss of control induced by the lesion. It appears that the transcallosal fibers in the patients might be associated with transcallosal disinhibition following brain injury.

In conclusion, we demonstrated abnormal transcallosal fibers in adult patients with brain injury. To our knowledge, this is the first study regarding abnormal transcallosal fibers which originated from the corticospinal tract of the unaffected hemisphere in the adult brain. We found that DTT technology would be a powerful, new means of revealing transcallosal fibers in patients with injury. This study invites a future longitudinal, prospective study in order to elucidate the association between the transcallosal fibers and the degree of motor recovery over time. A combined study using DTT, transcranial magnetic stimulation, and functional MRI would be more helpful in investigating the pathophysiological mechanism and clinical significance of the transcallosal fibers.

\section{요 약}

확산텐서영상은 뇌백질 영상화를 통한 피질 하 부위의 신경경로 연구에 매우 중요한 방법 이다. 본 연구는 뇌손상 환자에서 확산텐서 영
상을 이용하여 비정상적으로 피질척수로에서 나오는 뇌량 섬유로를 증명하려는 시도를 하였 다. 4 명의 뇌손상 환자와 14 명의 정상 대조군이 연구에 참여하였다. 확산텐서영상은 Synergy-L Sensitivity Endocinding(SENSE) 두부코일을 장착한 $1.5 \mathrm{~T}$ 자기공명영상장치(Philips Gyroscan Intera system)를 사용하였고, $\mathrm{F}$ 섬유로의 역치 는 $\mathrm{FA}<3.0$, angle change $>45^{\circ}$ 이었으며 3차 원적 재구성하였다. 14 명의 정상 대조군 중 2 명에서 횡뇌량 섬유로가 관찰되었고 이는 뇌량 을 거쳐 피질로 이어졌다. 4명의 환자군 모두 건측의 피질척수로에서 기인한 횡뇌량 섬유로 가 보였으며, 이는 피질하에서 병변의 주위 또 는 아래로 주행하였다. 건측 대뇌의 피질척수 로에서 발생한 횡뇌량 섬유로는 병적인 섬유로 로 운동능력 결손에 대한 보상적 역할을 하는 것으로 추정된다.

\section{References}

1. Basser PJ, Pierpaoli C. Microstructural and physiological features of tissues elucidated by quantitative-diffusion-tensor MRI. J Magn Reson B 1996 Jun;111(3):209-19.

2. Mori S, Crain BJ, Chacko VP, van Zijl PC. Three-dimensional tracking of axonal projections in the brain by magnetic resonance imaging. Ann Neurol 1999 Feb;45(2):265-9.

3. Jang SH, Kim YH, Kwon YH, You S, Han BS, Byun WM. Restoration of corticospinal tract compressed by hematoma: a diffusion tensor tractography study. Arch Neurol (in press).

4. Abe O, Masutani Y, Aoki S, Yamasue H, Yamada H, Kasai K, et al. Topography of the human corpus callosum using diffusion tensor 
tractography. J Comput Assist Tomogr 2004 Jul-Aug;28(4):533-9.

5. Dougherty RF, Ben-Shachar M, Bammer R, Brewer AA, Wandell BA. Functional organization of human occipital-callosal fiber tracts. Proc Natl Acad Sci USA 2005 May 17;102(20): $7350-5$.

6. Demeurisse G, Demol O, Robaye E. Motor evaluation in vascular hemiplegia. Eur Neurol 1980;19(6):382-9.

7. Aboitiz F, Montiel J. One hundred million years of interhemispheric communication: the history of the corpus callosum. Braz J Med Biol Res 2003 Apr;36(4):409-20.

8. Weiller C, Chollet F, Friston KJ, Wise RJ, Frackowiak RS. Functional reorganization of the brain in recovery from striatocapsular infarction in man. Ann Neurol 1992 May; 31(5):463-72.

9. Song YM, Lee JY, Park JM, Yoon BW, Roh JK. Ipsilateral hemiparesis caused by a corona radiata infarct after a previous stroke on the opposite side. Arch Neurol 2005 May;62(5): 809-11.

10. Turton A, Wroe S, Trepte N, Fraser C, Lemon RN. Contralateral and ipsilateral EMG responses to transcranial magnetic stimulation during recovery of arm and hand function after stroke. Electroenceph clin Neurophysiol 1996 Aug;101(4):316-28.

11. Netz J, Lammers T, Homberg V. Reorganization of motor output in the non-affected hemisphere after stroke. Brain 1997 Sep;120(Pt 9):1579-86.

12. Liepert J, Hamzei F, Weiller C. Motor cortex dishinibition of the unaffected hemisphere after acute stroke. Muscle Nerve 2000 Nov; 23(11):1761-3.

13. Manganotti P, Patuzzo S, Cortese F, Palermo A, Smania N, Fiaschi A. Motor disinhibition in affected and unaffected hemisphere in the early period of recovery after stroke. Clin Neurophysiol 2002 Jun;113(6):936-43. 